\title{
Exhaled Breath Analysis for Cancer Diagnosis and Screening
}

ISSN: 2637-773X

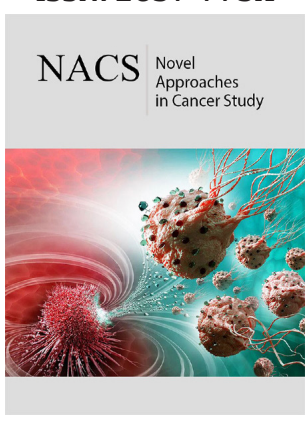

*Corresponding author: Li Lu, Department of Obstetrics and Gynecology, Hong Kong, China

Submission: 酶 September 23, 2019 Published: 此 September 30, 2019

Volume 3 - Issue 3

How to cite this article: Shao Y, Lin Y, Wang L, Mei F, Li L. Exhaled Breath Analysis for Cancer Diagnosis and Screening. Nov Appro in Can Study. 3(3). NACS.000562.2019.

DOI: 10.31031/NACS.2019.03.000562

Copyright@ Li Lu, This article is distributed under the terms of the Creative Commons Attribution 4.0 International License, which permits unrestricted use and redistribution provided that the original author and source are credited.

\author{
Shao $\mathrm{YF}^{1}$, Lin $\mathrm{YF}^{2}$, Wang $\mathrm{L}^{2}$, Mei $\mathrm{F}^{3}$ and $\mathrm{Li} \mathrm{Lu}^{4,5,6 *}$ \\ ${ }^{1}$ The First Affiliated Hospital, China \\ ${ }^{2}$ The First College of Clinical Medicine, China \\ ${ }^{3}$ Zhejiang University, China \\ ${ }^{4}$ College of Basic Medical Sciences, China \\ ${ }^{5}$ Department of Obstetrics and Gynaecology, China \\ ${ }^{6}$ Institute of Chinese Medicine, China
}

\begin{abstract}
Background: Nowadays, cancer is still one of the main fatal disorders in the world, from which the patients suffer a lot while the burden of the families and society increased. Early recognition and treatment are crucial to reduce the death rate; however, in clinical practice, many cancers could only be recognized when it comes to a later stage. With the development and progress of the modern medical technique, more and more novel testing methods are reported and under research. Many reports showed that dogs could smell out the cancer patients, and exhaled breath test with such as the gas sensor is gradually taking an important role in cancer early diagnosis and screening. However, systematic reviews in both fields are lacking.
\end{abstract}

Objective: We conducted this review to give an overview on the applications of dog olfactory detection and/or gas analysis technique in cancer early diagnosis and screening.

Method: Chinese National Knowledge Infrastructure (CNKI) and PubMed databases up to August 31st, 2019 were searched to identify relevant studies. All studies related to dog olfactory detection and/or gas analysis products in cancer early diagnosis and screening were summarized and further analyzed. There was no limitation on language of the publication. Data were extracted from all included studies and metaanalysis was performed with Review Manager 5.3. Pooled risk ratios (RR) or mean difference (MD) with $95 \%$ CIs were used to evaluate the effectiveness of dog olfactory detection and gas analysis technique application for cancer diagnosis.

Result: 10 dog olfactory detection studies in year 2006-2019 were identified, while the meta-analysis of 2 randomized experiments in dogs showed there was no significant difference between the early cancer diagnosis accuracy of canine scent detection and biopsy-confirmed ( $p>0.05)$. No clinical trials of gas analysis technique or product in human were identified, so no meta-analysis could be carried out. Different detection methods and gas analysis products for volatile organic compounds (VOCs) detection were summarized and their features, advantages and disadvantages were reported in detail.

Conclusion: The systematic review indicated that the analysis technique of VOCs from the human exhaled gas has the potential to be used for early cancer screening and diagnosis. The related techniques for VOCs detection are keeping developing, and the accuracy and specificity are continuously improved. However, more high-quality and large-scale randomized clinical trials are needed to confirm the effectiveness of exhaled gas analysis in cancer early diagnosis and screening.

\section{Background}

Cancer is one of the main diseases threatening the human life and health. Early recognition is crucial to increase the survival rate of cancer patients. However, current cancer early diagnosis faces many problems. For example, current early clinical diagnostic techniques have low specificity and sensitivity but need high cost. As the progress for the medicine, the new noninvasive and fast cancer early recognition technique has come out, which is of importance to decrease the death rate. Some research results indicate that the cancer patient could emit some special gas [1], and this provides the possibility to utilize the patient's emission gas for cancer screening, which is noninvasive, simple and sensitive. This diagnostic method has been adopted by using the trained dogs, which have the sensitive sense of smell [2]. And some research results have proven the possibility to use the dogs to realize the early diagnosis for 
such as the lung cancer [3], melanoma [4], bladder cancer [5] and so on. Nevertheless, the progress for these researches is limited for the training difficulty and non-controllability of the dogs. Therefore, the artificial olfactory system technique based on gas sensor comes out. We conducted this review to give an overview on the applications of dog olfactory detection and/or gas analysis technique in cancer early diagnosis and screening.

\section{Methodology}

\section{Literature search}

We performed a comprehensive search from Chinese National Knowledge Infrastructure (CNKI) and PubMed databases up to August $31^{\text {st }}, 2019$ for all the potentially eligible studies related to dog olfactory detection and/or gas analysis products in cancer early diagnosis and screening.

\section{Search strategy}

Keywords for the search included "olfactory detection", "dog detection", "canine scent detection", "scent detection" and "cancer early diagnosis" or "cancer diagnosis". For the CNKI database, the key words were searched in Chinese characters and Pinyin. There was no limitation on language of the publication.

\section{Data extraction and analysis}

We processed and analyzed the data using the Review Manager software (Revman 5.3, provided by the Cochrane Collaboration). Random-effects models were used to calculate pooled effects. Fixed-effect models were used for combining data where it was Table 1: Summary of dog olfactory detection studies. reasonable to assume that studies were estimating the same underlying treatment effect. Dichotomous data were presented as pooled Risk Ratio (RR) with 95\% confidence intervals (95\% CIs), while continuous data were presented as Mean Difference (MD) with 95\% CIs. We performed forest plot and funnel plot analysis to test heterogeneity and assess reporting biases. $\mathrm{P}<0.05$ was considered statistically significant. Heterogeneity was assessed through the $\mathrm{I}^{2}$ statistic, which estimates the fraction of variance that is due to heterogeneity and by $Q$ test. The level of significance for the $\mathrm{Q}$ test was defined as $\mathrm{P}<0.10$.

\section{Result}

\section{Animal study}

Ten dog olfactory detection studies in year 2006-2019 were identified, details are list as in Table 1 . Two studies reported the cancer diagnosis by canine scent detection in dogs [6]. The metaanalysis results showed that there was no significant difference between the canine scent detection and biopsy-confirmed groups [RR $0.84,95 \%$ CI 0.40 to $1.79, \mathrm{P}=0.65$, heterogeneity $2=142.11$, $\mathrm{P}<0.00001, \mathrm{I}^{2}=99 \%$ ] (Figure 1). It suggested that the accuracy of canine scent detection was the same as the pathological result as gold standard for cancer diagnosis. The analysis results conducted by the fixed-effect model are considered to show an "ideal/ typical intervention effect", and the baseline differences between the groups are considered as non-statistical heterogeneity. The heterogeneity is obvious in this meta-analysis, so the random effect model should be applied.

\begin{tabular}{|c|c|c|c|c|c|c|c|}
\hline No. & Year & $\begin{array}{l}\text { Study } \\
\text { Type }\end{array}$ & Country & Summary of Study & Disorder & $\begin{array}{l}\text { Detection } \\
\text { Sample }\end{array}$ & Remarks \\
\hline \multirow[t]{2}{*}{1} & \multirow[t]{2}{*}{2019} & \multirow[t]{2}{*}{$\begin{array}{l}\text { News } \\
\text { report }\end{array}$} & \multirow[t]{2}{*}{ USA } & $\begin{array}{l}\text { After } 8 \text { weeks of training, the } \\
\text { Beagle was able to distinguish } \\
\text { between serum samples from } \\
\text { patients with malignant lung } \\
\text { cancer and healthy controls. }\end{array}$ & \multirow[t]{2}{*}{ Lung cancer } & \multirow[t]{2}{*}{ Blood Serum } & \multirow{2}{*}{$\begin{array}{c}\text { Further isolate samples based on } \\
\text { chemical and physical properties until } \\
\text { specific biomarkers for each cancer are } \\
\text { identified. }\end{array}$} \\
\hline & & & & $\begin{array}{l}\text { Accuracy } 97 \% \text {. Double-blind } \\
\text { study. }\end{array}$ & & & \\
\hline \multirow[t]{2}{*}{2} & \multirow[t]{2}{*}{2019} & \multirow[t]{2}{*}{$\begin{array}{l}\text { News } \\
\text { report }\end{array}$} & \multirow[t]{2}{*}{ USA } & $\begin{array}{l}\text { A click-and-click training was } \\
\text { used to teach four beagles to } \\
\text { distinguish between samples of } \\
\text { normal serum and patients with } \\
\text { malignant lung cancer. }\end{array}$ & \multirow[t]{2}{*}{ Lung cancer } & \multirow[t]{2}{*}{ Blood Serum } & \multirow[t]{2}{*}{$\begin{array}{l}\text { Researchers speculate that dogs may } \\
\text { be able to identify cancer samples by } \\
\text { sniffing a biological compound. }\end{array}$} \\
\hline & & & & Accuracy $96.7 \%$ - 97.5\%. & & & \\
\hline \multirow[b]{2}{*}{3} & \multirow[b]{2}{*}{2018} & \multirow{2}{*}{$\begin{array}{l}\text { News } \\
\text { report }\end{array}$} & \multirow[b]{2}{*}{ Italy } & $\begin{array}{l}\text { After training, military dogs } \\
\text { could sniff urine samples to } \\
\text { determine whether their owners } \\
\text { had cancer. }\end{array}$ & \multirow{2}{*}{$\begin{array}{l}\text { Prostate cancer, } \\
\text { Bladder cancer, } \\
\text { Kidney cancer, } \\
\text { Lung cancer }\end{array}$} & \multirow[b]{2}{*}{ Urine } & \multirow{2}{*}{$\begin{array}{l}\text { Dogs may find abnormal physical condi- } \\
\text { tion of their owners according to their } \\
\text { different odors after having cancer. }\end{array}$} \\
\hline & & & & $\begin{array}{l}\text { Successfully detected urine } \\
\text { samples from patients with } \\
\text { different cancers, while smelled } \\
\text { urine samples from patients with } \\
\text { undiagnosed early cancers. }\end{array}$ & & & \\
\hline 4 & 2017 & $\begin{array}{l}\text { Liter- } \\
\text { ature }\end{array}$ & & $\begin{array}{l}\text { Dogs can sniff the skin and } \\
\text { exhale through sniffing. Odors } \\
\text { in odor, urine, body fluid and } \\
\text { blood were detected for different } \\
\text { cancers. }\end{array}$ & $\begin{array}{l}\text { Lung cancer, } \\
\text { Breast cancer, } \\
\text { Prostate cancer, } \\
\text { Ovarian cancer, } \\
\text { Melanoma }\end{array}$ & $\begin{array}{l}\text { Urine, } \\
\text { Body fluid, } \\
\text { Blood }\end{array}$ & $\begin{array}{l}\text { The metabolic odors of cancer patients, } \\
\text { such as exhaled gases, body fluids and } \\
\text { excreta, contain specific volatile odors } \\
\text { that healthy people do not have. }\end{array}$ \\
\hline
\end{tabular}




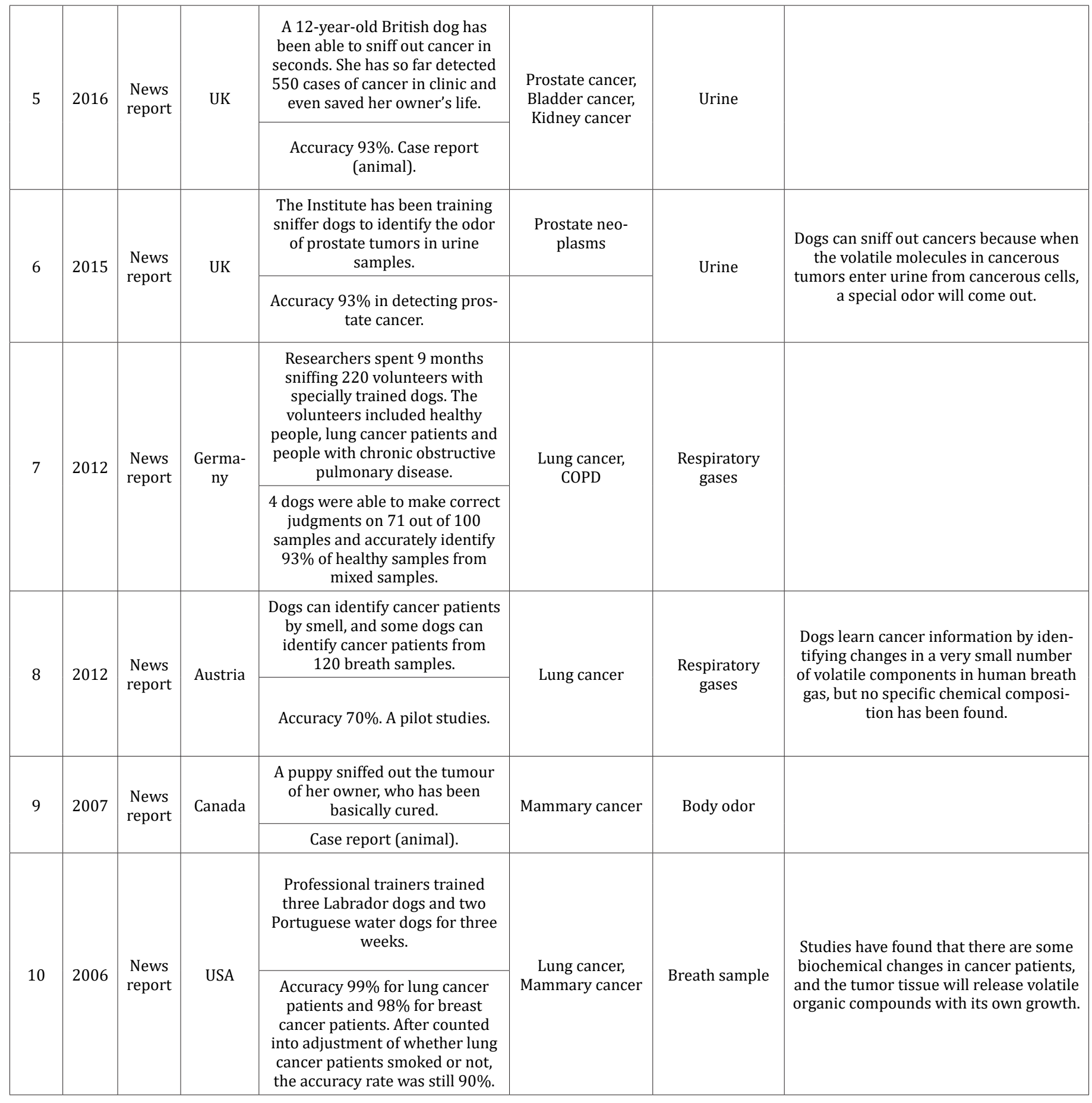

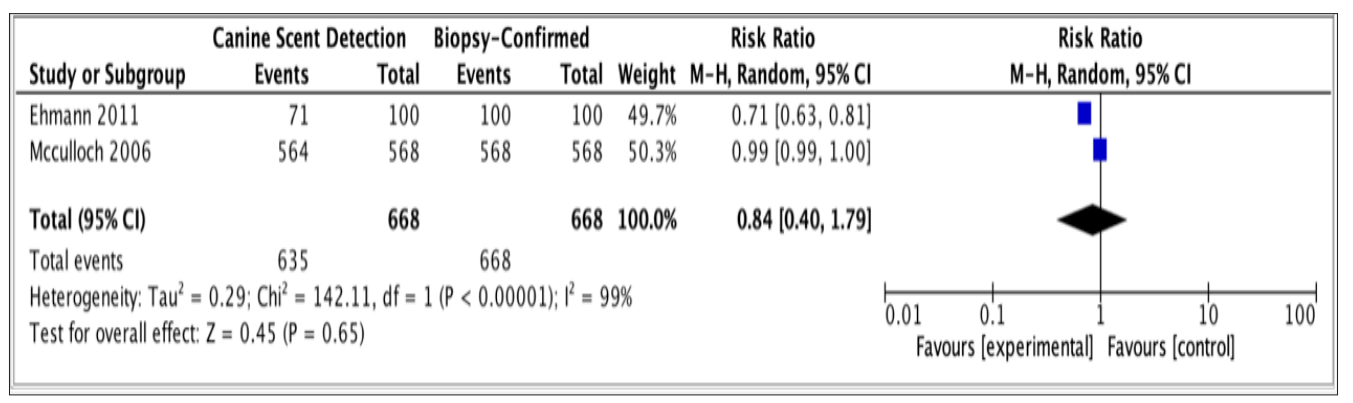

Figure 1: Preoperative 


\section{Clinical study}

No clinical trials of gas analysis technique or product in human were identified, so no meta-analysis could be carried out. Different detection methods were summarized in Table 2. Gas analysis products for volatile organic compounds (VOCs) detection and their features, advantages and disadvantages were reported in Table 3. Currently, the main gas sensing technique includes electronic nose technique, exhaled breath condensate technique, gas chromatographic analysis, mass spectrum analysis, gas chromatograph-mass spectrum analysis, optical techniques and so on [7]. The electronic nose technique utilizes the redox reaction between the target gas and the sensor material. When the redox reaction happens, the characteristics of the sensor material would be changed, and this change would be reflected in the sensor's output signal. And through monitoring the output signal, the target gas would be quantitatively detected [8]. This kind of sensor includes the metal oxide semiconductor sensor, surface acoustic wave sensor, quartz crystal microbalance sensor and so on [9]. These sensors could be arranged in arrays and combined with pattern recognition to simulate the human's olfactory system [10]. The main advantage for exhaled breath condensate technique is the detection for the generally used protein and gene type markers in the clinical diagnosis. These markers have been used for many years, and their accuracy and stability are positive. To clinician, the acceptance of this technique is higher than other ones. The gas chromatograph-mass spectrum technique separates the detected objects and using various detection equipment to quantitatively analyze and detect the separated objects. However, the high cost and difficulty in sample making limit the practical use in the clinical diagnosis for this technique [11].

Table 2: Summary of different detection methods.

\begin{tabular}{|c|c|c|c|c|c|c|c|}
\hline No. & Year & $\begin{array}{l}\text { Study } \\
\text { Type }\end{array}$ & Country & Summary of Study & Disorder & Detection Sample & Remarks \\
\hline 1 & 2018 & Literature & India & $\begin{array}{c}\text { The difference of light intensity loss } \\
\text { caused by thoracic movement during } \\
\text { breathing was analyzed. The respira- } \\
\text { tory frequency was calculated by data } \\
\text { output. }\end{array}$ & $\begin{array}{c}\text { Sudden infant } \\
\text { death syndrome }\end{array}$ & $\begin{array}{l}\text { Loss of light intensi- } \\
\text { ty during respirato- } \\
\text { ry cycle }\end{array}$ & $\begin{array}{c}\text { Neonatal respiratory monitor; } \\
\text { Optical Fiber Respiratory Sensor; It can } \\
\text { measure } 10 \text { to } 130 \text { breaths per minute } \\
\text { with an error of } 0.595 \% \text { and a lag error of } \\
0.2 \% \text {. The system display threshold is } 10 \\
\text { breaths per minute. }\end{array}$ \\
\hline 2 & 2018 & Literature & $\begin{array}{l}\text { Japan } \\
\text { Tokyo }\end{array}$ & $\begin{array}{l}\text { Reverse reaction of ethanol dehydroge- } \\
\text { nase (Adh): ACh is reduced to ethanol } \\
\text { and reduced nicotinamide adenine } \\
\text { dinucleotide (NADH) is consumed. The } \\
\text { concentration of ACh can be quanti- } \\
\text { tatively determined by fluorescence } \\
\text { detection of NADH consumed by ADH } \\
\text { reverse reaction. }\end{array}$ & cancer & Exhaled gas & $\begin{array}{c}\text { Fiber optic biosensor (biochemical gas } \\
\text { sensor); } \\
\text { Gas acetaldehyde (Ach) biochemical gas } \\
\text { sensor (biological sniffer); } \\
\text { Breath analysis. }\end{array}$ \\
\hline 3 & 2017 & Literature & $\begin{array}{l}\text { China } \\
\text { Tianjin }\end{array}$ & $\begin{array}{l}\text { Proton Transfer Reaction Mass Spec- } \\
\text { trometry; } \\
\text { Analysis of markers with high sensitivi- } \\
\text { ty and specificity. }\end{array}$ & Lung cancer & Patient exhaled gas & \\
\hline 4 & 2017 & Literature & Israel & $\begin{array}{l}1404 \text { patients and } 2808 \text { breath samples } \\
\text { were collected to analyze the exhaled } \\
\text { gas and diagnose the disease. }\end{array}$ & cancer & Breath samples & Nano Matrix Sensor Instrument \\
\hline
\end{tabular}

Table 3: Ten excellent artificial olfaction companies.

\begin{tabular}{|c|c|c|c|c|c|c|c|}
\hline No. & Company & Country & Field & Research direction & Financing & Product Features & Product Pictures \\
\hline 1 & Sensigent & USA & $\begin{array}{c}\text { Medical } \\
\text { diagnosis }\end{array}$ & $\begin{array}{l}\text { Sensigent was formed to } \\
\text { commercialize and market } \\
\text { advanced technology products } \\
\text { based on cutting edge research } \\
\text { performed by some of the } \\
\text { largest sensor and instrument } \\
\text { companies. The products are } \\
\text { used in diverse industries } \\
\text { including Petrochemical, } \\
\text { chemical, food and beverage, } \\
\text { packaging materials, plastics, } \\
\text { pet food, pulp and paper, med- } \\
\text { ical research, environmental } \\
\text { monitoring and many more. }\end{array}$ & $\$ 60$ million & $\begin{array}{l}\text { The Cyranose } ₫ 320 \text { is a fully integrat- } \\
\text { ed handheld chemical vapor sensing } \\
\text { instrument designed specifically to } \\
\text { detect and identify complex chemi- } \\
\text { cal mixtures that constitute aromas, } \\
\text { odors, fragrances, formulations, spills } \\
\text { and leaks. It is also used to identify } \\
\text { simple mixtures and individual chem- } \\
\text { ical compounds. The Cyranose® } 320 \\
\text { is used in diverse industries including } \\
\text { petrochemical, chemical, food and } \\
\text { beverage, packaging materials, plas- } \\
\text { tics, pet food, pulp and paper, medical } \\
\text { research, and many more. }\end{array}$ & 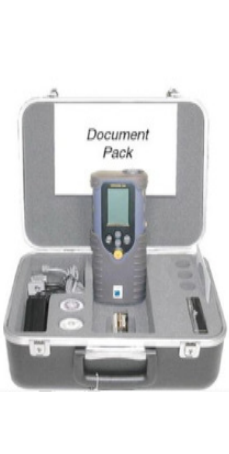 \\
\hline
\end{tabular}




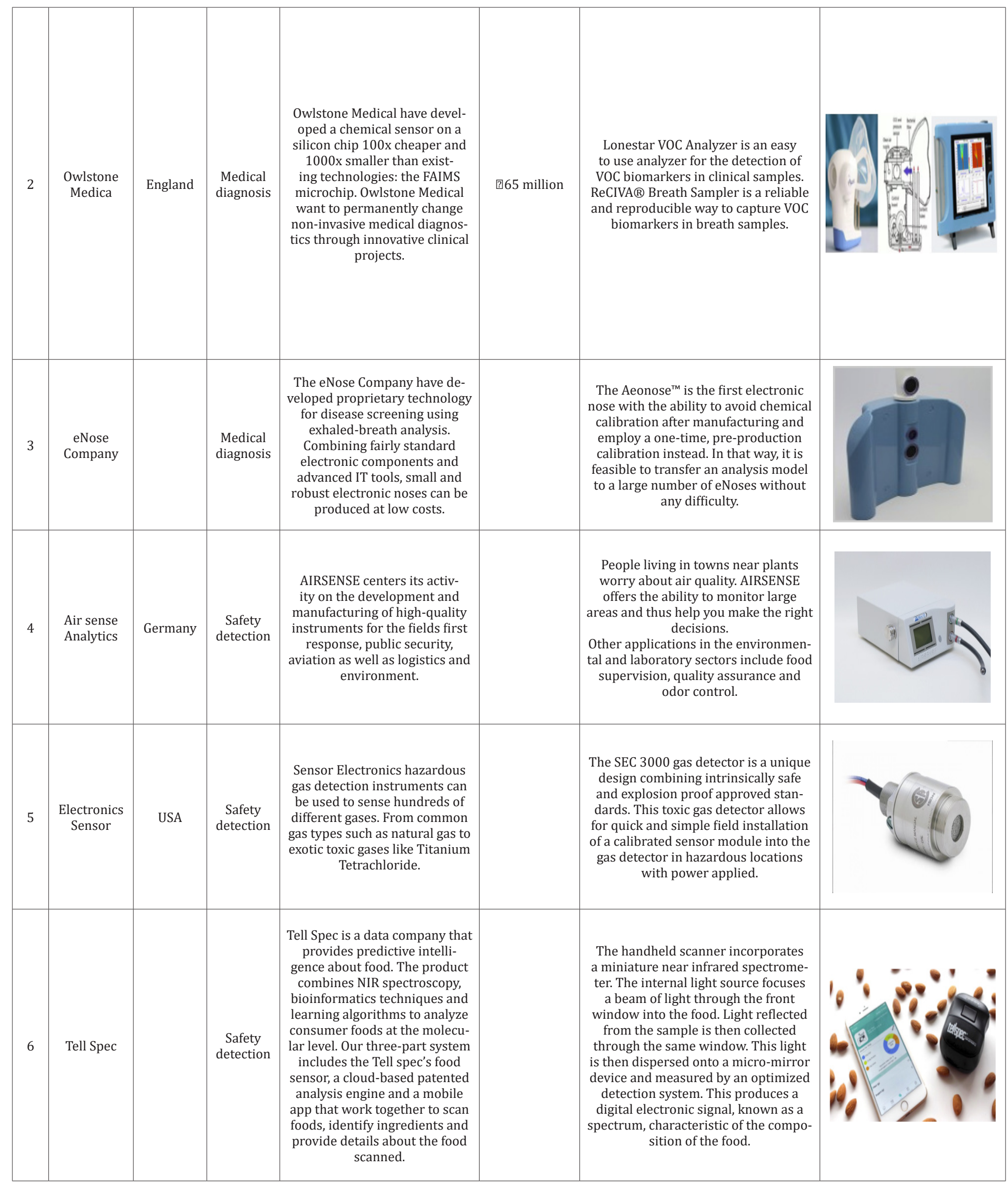






\section{Conclusion}

The systematic review indicated that the analysis technique of VOCs from the human exhaled gas has the potential to be used for early cancer screening and diagnosis. The related techniques for VOCs detection are keeping developing, and the accuracy and specificity are continuously improved. However, more high-quality and large-scale randomized clinical trials are needed to confirm the effectiveness of exhaled gas analysis in cancer early diagnosis and screening.

\section{References}

1. Gashimova EM, Temerdashev AZ, Porkhanov VA, Polyakov IS, Perunov DV, et al. (2019) Evaluation of the possibility of volatile organic compounds determination in exhaled air by gas chromatography for the noninvasive diagnostics of lung cancer. Journal of Analytical Chemistry 74(5): 472-479.

2. Guirao A, Molins L, Ramon I, Sunyer G, Vinolas N, et al. (2018) Trained dogs can identify malignant pulmonary nodules in exhaled gas. Lung Cancer 135: 230-233.

3. Pickel D, Manucy GP, Walker DB, Hall SB, Walker JC (2004) Evidence for canine olfactory detection of melanoma. Applied Animal Behaviour Science 89(1-2): 107-116.
4. Ehmann R, Boedeker E, Friedrich U, Sagert J, Dippon J, et al. (2012) Canine scent detection in the diagnosis of lung cancer: Revisiting a puzzling phenomenon. Eur Respir J 39(3): 669-676.

5. Willis CM, Church SM, Guest CM, Cook WA, McCarthy N, et al. (2004) Olfactory detection of human bladder cancer by dogs: Proof of principle study. BMJ 329: 712.

6. McCulloch M, Jezierski T, Broffman M, Hubbard A, Turner K, et al. (2006) Diagnostic accuracy of canine scent detection in early-and late-stage lung and breast cancers. Integr Cancer Ther 5(1): 30-39.

7. Lin LQ Dong H, Wang FY, Chen X (2016) Research progress of breath detection technology and equipment. Journal of Chinese Medical Equipment 31(2): 11-17.

8. Llobet E (2013) Gas sensors using carbon nanomaterials: A review. Sensors and Actuators B: Chemical 179: 32-45.

9. Sharma B, Sharma A, Kim JS (2018) Recent advances on $\mathrm{H}_{2}$ sensor technologies based on MOX and FET devices: A review. Sensors and Actuators B: Chemical 262: 758-770.

10. Konvalina G, Haick H (2013) Sensors for breath testing: From nanomaterials to comprehensive disease detection. Accounts of chemical research 47(1): 66-76.

11. Knutson MD, Handelman GJ, Viteri FE (2000) Methods for measuring ethane and pentane in expired air from rats and humans. Free Radic Biol Med 28(4): 514-519.

For possible submissions Click below: 